\title{
Proving nothing and illustrating much: the case of Michael Balint
}

\author{
Shaul Bar-Haim, University of Essex
}

In Thinking in Cases, John Forrester (2017a) does not provide us with one ultimate historical model for the 'case-based-sciences', but rather with several alternatives: a 'style of reasoning' (Hacking), 'paradigms' or 'exemplars' (Kuhn), and 'language games' (Wittgenstein), to mention only a few. But for Forrester, the stories behind each of the figures who suggested these different models are as important as the models themselves. The question for him is not only what is 'thinking in cases' but also who is a 'thinker in cases'?

Forrester's index of thinkers includes mainly two types: philosophers and historians of science (like Forrester), and psychoanalysts (Forrester's major object of study - indeed, his lifetime research). On the one hand, we have figures such as Thomas Kuhn and Michel Foucault; on the other hand, Sigmund Freud and D.W. Winnicott. In what follows, I argue that one figure is still missing from Forrester's collection of thinkers in cases: the BritishHungarian psychoanalyst, Michael Balint. ${ }^{1}$ This name is missing not only because Balint was a great 'thinker in cases', but also because we have some reasons to believe that Forrester himself thought so, and wished to add a substantive study of him to this book or to a future one. $^{2}$

\footnotetext{
${ }^{1}$ Balint was born in 1896 to a Jewish family. His father was a local doctor in Budapest, and Michael (originally Mihaly) followed him by studying medicine. Alice Szekely-Kovacs - later to become Mihaly's first wife introduced him to psychoanalysis by giving him Freud's 'Three Essays on the Theory of Sexuality' and Totem and Taboo. In 1919, he came to listen to the lectures of Sandor Ferenczi - the leading figure of the Budapest School, as well the most prominent psychanalyst after Freud in the international psychoanalytic community. When the extreme right winger Miklos Horthy came to power in 1920, Balint and Szekely-Kovacs - now a married couple - left for Berlin, where they were trained as psychoanalysts. In 1924 the Balints returned to Budapest, and became eminent figures in the local psychoanalytic community. After Ferenczi died in 1933, Balint became his successor as the Director of the public clinic of the Budapest Institute of. In 1938, after the Anschluss in Austria, and with the assistance of the British psychoanalysts Ernst Jones and John Rickman, the Balints managed to escape Hungary and arrived in Manchester, England. In August 1939, Alice suddenly died from of a ruptured aneurysm. Balint found a job in Manchester as a Child Guidance Clinic Director, where he also met his second wife Edna Oakeschott, an educational psychologist and a teacher at the University of Manchester. The couple got married in 1944, but got divorced just a few years after. After spending a few years in Manchester, Balint moved to London, opened a private practice and in 1948 joined the Tavistock Clinic. After a few years, he became one of the major figures in the post-WWII British School of Psychoanalysis. On Balint's life and work see Swerdloff, 2002; Sklar, 2017. On the Budapest School see Erős, 2012; Young-Bruehl, 2002; Rudnytsky, Bokay, and Giampieri-Deutsch, 1996. On Alice Balint's life see, Borgos, 2019.

${ }^{2}$ One may assume that Balint was not the only thinker in cases that Forrester did not have the chance to explore. Indeed, some of the articles in this special issue aims to fill this gap. See, for example, Burman (this issue), for the claim that 'Piaget's decades of experimentation afford an explicit embryology of human reasoning,
} 
Forrester himself explained to me almost ten years ago, the necessity of devoting a largescale research project to Balint. I came to meet him in his Head of the Department of History and Philosophy of Science office in Cambridge for hearing his opinion on my $\mathrm{PhD}$ proposal, which was supposed to focus on mid-twentieth century high-profile figures in British and Continental psychoanalysis, Balint included. Forrester has shown me some of his own works on the topic, suggesting that with one exception all this research that I proposed was already done. Balint and his work with GPs, he told me and perhaps to himself, is still unexplored terrain. I could learn to appreciate his advise only a few years later when visiting the Balint archives, then as a private collection, held by Balint successor André Haynal and stored in a small, stuffy, windowless room in the Library at the University of Genève (since then it was donated by Haynal to the Archives of the Institute of Psychoanalysis in London). ${ }^{3}$

Apart from many other invaluable private and professional documents, the archives contained the enormous number of minutes of what was known since the early 1950s as Balint Groups. The idea behind these Groups that Michael and his third wife, Enid, initiated and convene, was that GPs would meet regularly to discuss with their peers some medical cases studies with a psychosomatic nature from their own everyday practice. Thus, the Balints suggested, family-doctors would be better trained to handle what Balint called 'the psychological implications in general practice' (Balint, 2000 [1957]: 1). By and through these cases, Balint tried to help GPs develop a wide range of psychotherapeutic skills which were partly taken from the psychoanalytic tradition. Leading these groups of doctors also helped Balint to create a new theoretical vocabulary, one that was partly taken from psychoanalysis but specifically tailored to family doctors with the aim of enabling general practice to become a more holistic and psychosomatic discipline than it hitherto was. Balint was one of the most influential figures in postwar British psychotherapy and general practice, but he remained known only in limited medical and psychoanalytical circles, and with some few exceptions he is still largely understudied by historians (see however, Sklar, 2017; Hayward, 2014; Osborne, 1993; Soreanu, 2018; Bar-Haim, 2018). Thus, the minutes of Balint Groups meetings of over two decades, containing the stories of hundreds upon hundreds GPs patients

embedded in an implicit social ecology of knowledge... thinking in stages becomes thinking in a lineage of kinds, which we can think of as a variation through natural history of Forrester's thinking in cases' (??).

${ }^{3}$ When signing my name in the guest book, I was quite surprised to find so few names of people who visited before me. I do remember - although cannot guarantee - that John Forrester was one of them. 
from the 1950s and the 1960s, can shed light not only on the psycho-social turn in general practice in the first decades after the WWII, but also about Balint himself - about the 'case' of Michael Balint.

In preparing this article, I had the privilege to look at a very large computer file of notes that Forrester collected for many years for an unwritten book project, 'The Freudian Century'. ${ }^{4}$ Forrester's notes remained a work in progress, and as such it is difficult to tell what his vision was for this unwritten book. Rather than an outline for an argument, it is an outstanding collection of ideas, associations, quotations, and evidence chronicling the influence of figures and concepts - all about the huge cultural impact of psychoanalysis on $20^{\text {th }}$ century history. ${ }^{5}$ But the notes demonstrate a clear interest in Michael and Enid Balint and their Groups of doctors. In this computer file, which contains 775 pages and 329, 874 words, the word 'Balint' appears not less than 130 times, most of them in a section of 5,710 words about 'The Balintisation of the NHS: the doctor as psychotherapist' (Forrester, undated). It seems like this part of the book was supposed to provide a history of what was known as the Balint Groups movement, its great success in the 1960s and 1970s, and its decline in the 1980s (see sub-section about 'the death of Balint Movement in the 1980s?'). When reading more closely, it becomes clear that Forrester's interest in Balint comes from his attempt to portray the Balint Groups movement as an emblematic case study for understanding the influence of psychoanalysis on the construction of the British welfare state; and also, to demonstrate how this post-WWII's school of psychoanalysis can be a useful source for thinking in cases. In what follows, I will first present the Balintian project before arguing that, for Forrester, Balint's work serves as an exemplar for the case-based-sciences that can connect both traditions mentioned earlier: the historical and philosophical on the one hand, and the clinical one, on the other hand.

\footnotetext{
${ }^{4}$ I'm so very grateful to Lisa Appignanesi for allowing me an access to John Forrester's notes on his unfinished.

${ }^{5}$ The entries could be as different as suggesting to think of 'Freud as medieval Jewish physician-philosopher (Maimonides?)', to explore 'psychoanalytic student songs in Moscow, 1920s', to reflect on 'Bill Clinton's letter of condolence to Erik Erikson's widow', or on the differences between Marilyn Monroe's analyst and Monica Lewinsky's therapist way of talking on their famous patients in public.
} 


\section{Proving nothing an illustrating much: The psychoanalytic 'case' between Freud and Winnicott}

Any discussion about the psychoanalytic case-study goes directly back to the founding-father of the field, Sigmund Freud. He is arguably the most 'paradigmatic' thinker in cases in the psychoanalytic tradition precisely because, for him, the singular case study was always the main tool for demonstrating the validity of a theoretical concept (Anna O - 'hysteria'; Dora 'transference'; Schreber - 'paranoia' etc.). In no other place in Freud's corpus is this method more telling than in his Interpretation of Dreams (1900) where psychoanalysis itself emerges out of one major single case study - that is, Sigmund Freud himself. According to Forrester, it is this 'shared example' of the founding father of psychoanalysis that enables 'psychoanalytic discourse [to combine] two unlikely features: it promises a new way of telling a life in the 20th century, a new form for the specific and unique facts that make that person's life their life; and at the same time, it attempts to render that way of telling a life public, of making it scientific'. The 'case history', Forrester explains, is 'the bridge between these two aims' (Forrester, 2017:12).

Interestingly, however, it seems like it was actually D.W. Winnicott - and not Freud - who understood the complex scientific status of case studies in the same way as Forrester; for Winnicott, as for Forrester, 'one case proves nothing, but it may illustrate much' (Winnicott quoted in Forrester, 90). In his chapter on Winnicott, Forrester analyses a single case study of Winnicott, entitled 'A Child Psychiatry Case Illustrating Delayed Reaction to Loss' (Winnicott, 1965). At the center of this case stands Patrick, who suffers from a mental breakdown after losing his father on his eleventh birthday. The father drowned while holding Patrick above the water. The father, then, literally saved his son's life by holding him, a gesture that Winnicott symbolically reproduced through his clinical emphasis on a form of therapeutic 'holding environment' ${ }^{6}$ However, rather than being a 'passive' psychotherapist, Winnicott at first avoided doing any interpretative work and instead used his medical authority to bring Patrick back home from his boarding school, where they 'could not believe that Patrick was really ill' (90); then, he 'persuaded the mother to postpone her own mourning of her husband and occupy herself with her son' (91). The mother, readers learn

\footnotetext{
6 'Holding' has a genuinely specific meaning in Winnicott's clinical theory. See Abram, 2007:193-199.
} 
after Patrick recovers, felt neglected by Winnicott and could not understand why he would not treat both of them, both she and her son:

It was as if Winnicott made a quick calculation: both need help, but it is the boy who needs help far more, and the mother will just have to shoulder the burden of Patrick's cure. It is either her or him. And Winnicott made it difficult for the mother to refuse to sacrifice herself for her son, and thus repeat her husband's self-sacrifice. Winnicott highlighted for himself and for the reader the fact that the mother might also have been aware of the metaphoric resonances of the holding-cure that Winnicott asked her to conduct (91).

Rather than taking a 'metaphoric' role of a father - the kind of symbolic Function that psychoanalyst might take when treating patients - Winnicott took on himself the paternal role itself, which at the time included also to some extent replacing the dead father, and managing the family. The literal 'holding' of the dead father when tried to save his son's life was now replaced by a different - although not less 'real' - form of paternal 'holding', a job that Winnicott took on himself.

Winnicott's paper, says Forrester, 'is also an illustration - this is a word Winnicott was very fond of using when talking of cases' (90). But what is it that, according to Winnicott, cannot be proved by a single case study, and what exactly can be illustrated by it? And why did Forrester find this approach so appealing? One possibility is that he found in Winnicott a better contender for the scientific status of psychoanalysis than Freud. Like many other postFreudian psychoanalysts, Winnicott gave up on the $19^{\text {th }}$ century commitment to an 'objective' science, which Freud thought as the desired model for psychoanalysis. ${ }^{7}$ Thus, like other postFreudians, the question of the scientific validity of psychoanalysis was not a central one for Winnicott. In fact, by abandoning the strict scientific pretentions, Winnicott got very close to Kuhn, who argued that a paradigm is precisely 'what you use when the theory isn't there' (quoted in Forrester, 36-7 [italics in original]). ${ }^{8}$ The failure to prove a scientific theory could

\footnotetext{
${ }^{7}$ As Alfred I. Tauber noted, 'positivism, which seeks radically neutral and objective knowledge... organized Freud's ever-present desire to legitimize psychoanalysis by linking its theories and the clinical data upon which they were based with those sciences that he thought had achieved a kind of objectivity he admired' (2009:34).

${ }^{8}$ Kuhn became gradually unhappy with the term 'paradigm' (the center of his most famous and successful book, The Structure of Scientific Revolutions). Rather than using the term 'paradigm' to describe what is common in a scientific community of a specific time and place, Kuhn thought that it would be better to talk about exemplars, that is, 'shared examples [that] ground the productive collective labour of a scientific community' (Forrester,
} 
be at the same time the success of illustrating something profoundly important for a scientific community, even if it cannot - or cannot yet - produce a full theory.

Furthermore, Winnicott helps Forrester to show how clinical cases can serve as a bridge between metaphors and the reality that these metaphors aim to symbolize. Dora's case, for example, cannot prove 'transference' as a theory, but it can illustrate what the metaphor of transference does in psychoanalysis. Similarly, when Winnicott talks about analysts 'holding' their patients, he does not necessarily mean literally to hold the patient in the same way that a mother - or, in Patrick's case, the father - holds a child. However, Forrester explains, 'the aim of analysis is to restore to metaphors their metaphoricity: their ability to carry' (Forrester, 2017a:104). ${ }^{9}$ Put differently, in Forrester's reading of Winnicott, metaphors need to serve as a bridge between the clinical practice and its yet-to-be-written theory. Therefore, successful metaphors, like good case studies, prove nothing but illustrate much.

Winnicott is perhaps the most known figure in the postwar British tradition of psychoanalysis. However, the intellectual origins of what is known as the postwar British School of Psychoanalysis that Winnicott is so identified with are not solely British. British psychoanalysts before and after the WWII were very much influenced by the early $20^{\text {th }}$ century Budapest School of Psychoanalysis, established by the influential psychoanalysts Sandor Ferenczi and his successors, Michael Balint more than anyone else. Indeed, As this 'knowledge in transit' (Secord, 2004) between Budapest and London is now well documented (Bar-Haim, 2019; Soreanu, 2018, Eros, Szekacs-Weisz, and Robinson, 2013), it should not come as a surprise, then, that Winnicott and Balint were part of the same tradition of thinking in cases.

\section{Michael Balint: A thinker in cases}

2017a:7). Not only for Kuhn, but also for Forrester, exemplar is a much more useful concept for 'the casebased-sciences' (e.g., medicine, law, psychology) than paradigm. In fact, exemplar is one way of thinking in cases: 'One learns how to do science not by learning the rules or principles or concepts and then applying them to concrete situations; rather, one learns how to do science by learning how to work with exemplars: extending them, reproducing them, turning a novel situation into aversion of a well-understood exemplar' (7-8). The case study as an exemplar is always a narrative of an individual that can tell us only about its own singularity unless a professional community can 'tie cases together in rational and defensible network' (Forrester, 2017a:49). Indeed, 'it is the task of the professional community's internal communications' (ibid) to do so, explains Forrester.

9 Winnicott, however, did occasionally try to hold patients in a maternal manner. See for example, Little, 1985. 
In psychoanalytic circles, Michael Balint is identified with the Independent Group in the Institute of Psychoanalysis. This Group was born from the famous debate in the early 1940s between Anna Freud and Melanie Klein, along with their respective followers. In that debate - known today as the 'Controversial Discussions' - several psychoanalysts, including figures such as Winnicott, Bowlby, Sharpe, and Fairburn, refused to pick sides in this theoretical argument between the two first ladies of British psychoanalysis. They increasingly felt that their theoretical and clinical views were not well represented in this crucially important argument on the future of British psychoanalysis, which pushed them to offer, in the years to come, a third alternative, and to establish a third Independent Group, in which Winnicott and Balint were two of the main architects.

On the one hand, the members of the Independent Group were identified with the 'maternal shift' that Klein advocated, and argued that the first bond between the mother and her child is the most crucial stage in the psycho-social development of the child. Indeed, they all perceived this first maternal attachment as a model for an ethical bond - a paradigm for human relationships which are based on care and intimacy rather than on rivalry, penis envy, and castration anxiety, as Freud arguably suggested in his Oedipal model. On the other hand, however, there were many other ways in which members of the Independent Group were analytically closer to Anna Freud, especially in their insistence that external reality matters and makes a difference in children's development. If Melanie Klein believed that people's emotional life is determined by their inner psychical world, and not necessarily by external reality, Anna Freud, Winnicott, and Michael Balint thought that the psyche of children and adults is precisely the meeting point of their inner unconscious life and the external world namely society, represented initially by the mother. Balint had a tremendous influence on this tradition, partly by implementing some of the language of his mentor Ferenczi, who was known as the first psychoanalyst to focus on the maternal role in psycho-social development. ${ }^{10}$

However, during the 1950s Balint also became known, this time in medical circles, also for his other project mentioned earlier, namely the Balint Groups. What started at the Tavistock in 1950 as an experimental peer-group for general practitioners (GPs) became in the next few

\footnotetext{
${ }^{10}$ On the Independent Group see Kohon, 1985. For the history of British psychoanalysis in the mid-twentiethcentury, see Shapira, 2013; on the debate between Anna Freud and Klein see, Steiner and Pearl, 1991; Shapira, 2017; Bar-Haim, 2017. On the Ferenczian tradition and its impact on British psychoanalysis see Bar-Haim, 2014.
} 
decades an international movement that still exists today all over the world (Bar-Haim, 2018). Providing a detailed history of the Balint Groups movement - a research project that Forrester himself found woefully lacking - is beyond the scope of this article. In the remaining space, I show instead how much Balint's thinking was imbued with cases and with thinking by and through case studies. As his now classic book The Doctor, His Patient and the Illness (1957) demonstrates, case studies were Balint's main tool in building his theoretical apparatus for the study of the psycho-medical sciences. The book shows how Balintian notions like the 'drug "doctor"', 'collusion of anonymity', and 'apostolic function' emerged from actual case studies, taken from GPs' consulting rooms. Indeed, the Balintian model is based on the accumulated medical experience of Balint Group members. And yet, to understand each concept, one does not necessarily have to trace back the process of collating these cases as Balint and his colleagues did. One only needs to read one of the cases, which, as Winnicott suggested in what Forrester took as another model for thinking in cases, may prove nothing but illustrate much.

In what follows, Balint's late article, 'Psycho-Analysis and Medical Practice' (1966), will serve as a paradigmatic text for the reconstruction of the Balintian method for thinking in cases. In this article, Balint uses what he calls one 'illustrative case' (p. 57) - taken from one of his GP groups - to argue that if psychoanalysts wish to be more influential in GPs' medical training, they should give up some of their psychoanalytic principles, and collaborate with GPs as equal researchers, rather than dogmatically educating them to treat patients in ways that do not fit their nature as 'family doctors'. At the same time, this single illustrative case study helped Balint to demonstrate his notion of the doctor's 'apostolic function', which Balint thought as closely related to the psychoanalytic concept of a 'countertransference'. However, 'Psycho-Analysis and Medical Practice' is useful for our purposes here also because it was a main source for Forrester in his notes for his research plan into the Balint project - the same research that he did not have the time to carry out. Finally, Balint's article will serve us for exploring some affinities between the Balintian notion of 'apostolic function' and Forrester's interest (follows Foucault) in the role of 'pastoral power' and 'pastoral care'.

\section{What general practitioners can (and cannot) learn from psychoanalysts?}

The article begins by suggesting that a major shift occurred in general practice after the 'realization that a substantial number of people asking for surgical and medical assistance are 
in fact suffering from emotional problems' (Balint, 1966:54). For Balint, the problem was that these doctors do not have any knowledge or experience in using therapeutic methods, and the question is whether the psychoanalytic movement would be able to fill this void by providing relevant training. 'Shall we analysts accept any responsibility in this field?', asked Balint, and if so 'what sort of responsibility?' (ibid).

Balint thought that this historical moment is an opportunity for the psychoanalytic movement to fulfill an old Freudian and Ferenczian vision: namely, using psychoanalysis to turn medicine into a psychosomatic field of knowledge and practice, as well as have more knowledge about what he would call the 'drug-doctor' (Bar-Haim, 2018). If we accept, however, that psychoanalysis should participate in this new effort to help doctors better cope with the emotional aspects of their patients' problems, then 'which roles are open to us psycho-analysts in this new field of training, and what it would mean to accept one role or the other' (55), he asks. Balint suggested that there are two alternative roles for psychoanalysts to take in such future training: the educator and the researcher.

Psychoanalysts, he claimed, are naturally much more comfortable taking the role of the educator which they do so regularly when teaching and supervising candidates in training schemes of psychoanalytic institutes. In these training programs, they are mainly worried about their candidates not becoming 'wild analysts', or making terrible clinical mistakes that will damage patients. Therefore, in training schemes, psychoanalysts put most of their effort into giving advice about what candidates should not do in the consulting room (ibid). They often recommend their trainees to be very strict with the 'setting' of the psychoanalytic treatment, to stick to formal face-to-face sessions, and not to intervene in the flow of patients' 'free associations'. The main advantage of a training structure in which senior psychoanalysts mentor their juniors is the dissemination of theoretical knowledge - and, indeed, senior analysts tend to spend long spans of time lecturing their candidates and younger psychoanalysts on their theoretical beliefs.

But even if the psychoanalytic training schemes worked well for psychoanalysts (and the slightly sarcastic tone Balint used when discussing this subject suggests that he did not think so), he believed that these methods are not relevant to the 'family doctor', as Balint preferred 
to call the GP in this case. ${ }^{11}$ The training of psychotherapeutic technique is the right one for this specific 'artificial situation created by us [psychoanalysts]' (56), he argued. But the family doctor works in a different setting and under different circumstances. For example, while the psychanalytic setting is designed for a 'two-person relationship', the GP is the 'doctor of the whole family'. As he explains,

the doctor maintains a close therapeutic relationship with every member of the family, the intensity of which varies with the member's personality and with the urgency of his complaints, but it is hardly ever an exclusively two-person relationship. If a particular member of the family has some complaints, worries, or is 'ill', the relationship between him and the doctor becomes for a period more intense, more intimate, and he gets special attention. At the 'end of the illness', however, this special attention is automatically withdrawn and given to another member of the family, and so on. (56).

For Balint, the psychoanalytic educational model is based on theoretical knowledge which is relevant only to the specific 'artificial' situation of analysis; once the setting is different, this model collapses. Therefore, Balint argued, GPs who wish to provide their patients with some psychotherapeutic tools will find psychoanalysis not very useful because of its dogmatic organization of the setting. The fact that a patient cannot be treated by the doctor totally separate from the whole family is particularly at odds with the psychoanalytic tradition, which was originally designed as a two-persons relationship - that is, between the doctor and the patient. Thus, the educational model of psychoanalytic training schemes will not be useful for GPs because of the nature of their profession, and because it was designed with some theoretical assumptions that cannot be applied by family doctors.

\section{The case of Mrs. Q. proves nothing but illustrates much (about the GP's 'apostolic function')}

In one of the notes to his unwritten 'Freudian Century' Forrester suggested that the Balint Groups movement ideologically aimed to protect doctors against some collective "power fantasies', as he called them. A major one of these fantasies was the 'idea that psa [sic] can

\footnotetext{
${ }^{11}$ Balint was a consistent critic of the psychoanalytic training system in Britain. See, for example, Balint, 1948, which was one of first papers that he published after escaping to Britain.
} 
take over medicine, so that doctor becomes simply analyst of patient's demand' (Forrester, undated). ${ }^{12}$ In the same vein, also Balint opposed the idea that psychoanalysis should serve as a meta-discipline for all the other psycho-medical sciences. Indeed, for him, rejecting the 'educational model' in the training of psychoanalysts was also a critique of some 'imperialistic' tendencies of psychoanalysis, and the utopia that it could become a metahuman science that can be used for all social and medical purposes. Instead of the 'educational model' for training candidates in psychoanalytic institutions, Balint presented an alternative model for training candidates in the medical professions which is still based on therapeutic tools taken from the psychoanalytic tradition - i.e., the 'countertransference' or the 'apostolic function' - but yet a model which is not committed to all human sciences, or even all case-based-sciences. Loyal as ever to his own way of thinking in cases, he now turned to present his new model through an 'illustrative' case study. That is, Balint illustrated the way in which 'countertransference' can be useful in the work of the GP. As Freud used his known case studies for illustrating one concept (for example, the case of 'Dora' for illustrating the idea of 'transference'), so was Balint who picked one case study for illustrating one concept (the case of Mrs. Q for illustrating 'countertransference'). ${ }^{13}$

Mrs. Q used the opportunity of her doctor's arrival at her house to treat her daughter Leslie's asthma attack with an adrenalin injection to complain of 'severe abdominal pain and threatened to faint' (57). According to the GP, 'Mrs Q is suffering from functional or hysterical abdominal pains, complicated by chronic constipation' (ibid). In fact, this constipation goes back 10 years earlier to the time Mrs. Q arrived in London form Ireland. The doctor 'diagnosed it as a functional disease due to some unspecified emotional problem' (ibid). Mrs. Q., however, insisted that this is an 'organic' illness, and demanded to have 'specialist examinations', which the doctor refused. He suggested instead psychotherapeutic help, which she and her husband rejected. Both told the doctor 'practically in so many words, to mind his own business' (57-8).

The discussion in the Balint group in which the doctor was a member focused on whether or not the 'firm attitude' of the doctor played a role in the hostile atmosphere between the doctor

\footnotetext{
12 The vision of psychoanalysis as a meta-discipline was beast articulated by Freud himself in his essay on 'The Question of Lay Analysis' (1926).

${ }^{13}$ However, while both Freud and Balint shared the method of using one case study for illustrating one theoretical concept, for Freud it was not only an illustration - he truly believed that it was an attempt to provide a strictly scientific evidence for the validity of a concept.
} 
and the family. Some supported this approach, but others thought that it was precisely this attitude that became part of the problem: 'we established a maxim that if the doctor feels anything when attending to his patient he should on no account act upon his feelings, but should stop and examine them as a possible symptom of his patient's illness' (58). The doctor agreed to assess his own role in Mrs. Q's difficulties, and decided to change his attitude: although he remained skeptical about the physical origins of her symptoms, he offered Mrs. Q a long interview only to inquire about the medical state of her bowels. From this interview, he then suggested that she see a specialist for a check-up. Mrs. Q was so pleased by her doctor's changed attitude that she immediately disclosed to him more details of her past:

The doctor learned that her father was a friendly, very peaceful man, while her mother was a bossy, dominating woman. When the doctor interjected, 'Somewhat like you?', the patient smiled and continued that her mother left her father and came to live next to the patient which resulted in quarrels and a rather strained atmosphere. The doctor then asked if all this anger and quarrelling may have had some effect on Leslie's asthma, whereupon the patient answered, 'Perhaps', and departed in a friendly mood (ibid).

Following this meeting, the abdominal pain disappeared, and the doctor learnt that for a while the patient did not use the referral letter that he gave her to see a specialist. The doctor's changed attitude created a totally new atmosphere between him and the patient and both were 'now working together with the production of quite impressive material', which included some information about the possible psychosomatic nature of Leslie's asthma. The doctor now learnt that 'Leslie was quite well while the family lived in a somewhat dilapidated house from which they were moved by the local authority to a rent-assisted new flat' (58). In other words, it is the doctor's self-reflection - his 'countertransference', or what Balint called the 'apostolic mission' - that created the shift in Mrs. Q's treatment (on the affinities between the two concepts will be discussed shortly).

When the doctor came to Mrs. Q's family flat again following another of Leslie's asthma attacks, he now asked the mother, Mrs. Q, to administer an aminophylline suppository. The mother failed to control Leslie, and the doctor had to intervene and to do it by himself. Only then Leslie calmed down, 'the doctor tucked her back in bed, kissed her goodnight, and left' (59). However, as the doctor admitted to the group, this scene made the doctor more 
concerned as 'the whole family Q was, so to speak, starved for kindness and affection, and he saw the danger that after they had discovered that they could get something of it from their doctor, they might have to demand more and more'. But another doctor ('a women doctor') of the group suggested that everything thus far suggested that the treatment was effective and there was no need to worry: 'Mrs. Q saw, perhaps for the first time in her life, what affectionate handling was' (59). In other words, she suggested that the doctor illustrated what affection is or might be. This could not be illustrated other than by performing it in a real event, as had happened. However, it also could not happen if the doctor did not assess his own 'apostolic function', or the 'countertransference' as a doctor:

[T]he doctor was helped to discover for himself that his 'firmness', that is, his way of practising medicine, was the result of an interplay between the patient and himself, was in fact a symptom of his patient's illness which brought forth a reaction (countertransference) from him. He had been aware for some time that his 'firmness' led to undesirable therapeutic results. His new discovery, therefore, increased the burden of his therapeutic responsibility. Of course, he could have denied the whole connexion [sic], but in this case he decided to experiment with new attitudes (61).

Thus, we can see that the crucial factor in the doctor's ability to help Mrs. Q was his willingness to use his 'countertransference', namely to learn something new about his own emotions and behaviors in this specific relationship between him and this patient. Indeed, it was the 'countertransference' that served Balint as a model when developing the notion of the 'apostolic function'. Interestingly, however, Balint insisted on keeping these two terms separated and not to replace one with the other. In order to understand the connection between 'countertransference' and the 'apostolic function' we should first look briefly at the origins of the former concept; and the ways in which its emergence undermined Freud's perception of the psychoanalyst as an 'objective' observer of his patients.

For Freud, the ideal psychoanalyst is an 'objective' scientist, 'a black mirror', to which the patient can project his or her free associations. Under such conditions a clinical 'transference' can take place:

What are transferences? They are new editions or facsimiles of the impulses and phantasies which are aroused and made conscious during the progress of the analysis; but they have this peculiarity, which is characteristic for their species, that they 
replace some earlier person by the person of the physician. To put it another way: a whole series of psychological experiences are revived, not as belonging to the past, but as applying to the person of the physician at the present moment (1905 [1901]:116).

The act of replacement and re-enactment of relationship of a person from the patient's past with the figure of the psychoanalyst stands at the centre of the Freudian technique. But Freud did not appreciate the fact that also the psychoanalyst brings his or her own subjectivity to the consulting room. Thus, there is not only a transference in the relationships of patients and doctors, but also unconscious countertransference (Laplanche and Pontalis, 1988: 92-3; for the history of the concept of 'countertransference' see Stefana, 2017; Racker, 1988). Therapeutic relationships are series of role-playing between - as well as encounters of - two subjectivities, not one. However, in acknowledging the existence of the countertransference one also must acknowledge the existence of different positions of power-relations in the clinical relationships: the vulnerable patient, on the one hand, and the doctor, an embodiment of medical authority, on the other hand. The challenge of the post-Freudian psychoanalyst was to be aware of that dynamics and to use it for helping the patient rather than exploiting this power by any means.

In 1939, Alice and Michael Balint published their article 'On transference and countertransference', in which they suggested that 'the analyst must be required to make himself conscious of every emotional gratification brought about by his individual technique, in order that he may keep a better control upon his behavior - and upon his theoretical convictions' (229-30). Thus, acknowledging and working with the analyst's 'countertransference' became one of the main responsibilities of the post-Freudian psychoanalyst. According to Balint, the GPs must have similar responsibility of making themselves fully conscious to their own emotions when treating patients with emotional problems. Balint, however, acknowledged that the psychoanalytic vocabulary cannot be easily translated into general practice, and therefore suggested specific vocabulary to be used by family doctors. What was known in psychoanalysis as 'countertransference' turned in the Balintian discourse into 'apostolic function'.

While rejecting the traditional training schemes of psychoanalytic institutes (the 'educational model'), Balint did suggest that psychoanalysts will help GPs to explore the 'doctor's 
countertransference to his patient' (60). However, he had some reservations about using this term 'countertransference':

There are several synonyms for describing the same phenomenon. It may be called the doctor's contributions to the developing doctor-patient relationship; the doctor's individual ways of practising medicine; the doctor's emotions; or the doctor's apostolic function (ibid).

The last option is a core concept in Balint's work with doctors, which he now admits was partly taken from the psychoanalytic thinking on 'countertransference'. By 'apostolic function' Balint (1957) means the 'vague, but almost unshakably firm idea of how a patient ought to behave when ill... It was almost as if every doctor had revealed knowledge of what is right and what was wrong for patients to expect and to endure, and further, as if he had a sacred duty to convert to his faith all the ignorant and unbelieving among the patients' (216). Like the psychoanalyst's countertransference, the GP will do better if he or she acknowledges their 'apostolic function' since lack of awareness to this dimension in their profession could be a major obstacle for them in helping their patients, as the case of Mrs. Q illustrated.

\section{Between Balint and Foucault: on pastoral power and the doctor's 'apostolic function'}

This 'apostolic function' is not unrelated to what Foucault defines as 'pastoral power', which as mentioned above, Forrester thought of as a crucial dimension in explaining not only the modern history of the clinical professions, but also for explaining modernity itself. ${ }^{14}$ The Greek city, Foucault argued, provided us with a political model for citizenship, but with 'no model for the care of individuals by the State' (Forrester, 2017b:223). It was the 'Oriental societies: Egypt, Assyria, Judaea' (Foucault, 1979:51) - and more perhaps than any other society before, the Hebrews - from which Christianity took the notion of a 'shepherd-God' who

watches over his flock rather than his land, bringing together dispersed individuals, guarding over them at every moment in a devoted spirit. Hence there are two forms of power: one political, one pastoral. Political power, the Greek model, provides the

\footnotetext{
${ }^{14}$ On the development of the notion of 'pastoral power' in Foucault's thought see Golder, 2007; on the genealogy of 'pastoral economy' in Christian thought see Leshem, 2014.
} 
legal framework of unity; the role of pastoral power is to 'constantly ensure, sustain, and improve the lives of each and every one' [quoted from Foucault, 2013:55] (Forrester, 2017b:223). ${ }^{15}$

Forrester relies here on Foucault's lecture 'Politics and Reason' (1979), in which the latter developed the idea of a pastoral power, but also of pastoral care. This was a very specific moment in Foucault's later thought wherein he gradually turned away from his long interest in models of modern power as forms of domination, to develop his study of 'biopower' 'governmentality', and the 'care of the self' (Burchell et al, 1991; Davidson, 2011; Behrent; 2016). The late Foucault attracts fierce debates between his scholars, especially on how to understand his turning away from some previous theories of power, as well as on his late1970s critique of the post-WWII Marxist legacies in France. While some of his followers argue that Foucault wished to think beyond the framework of the postwar 'welfare state' which many in the left considered by then as a disappointing project, other scholars argued that in his total resistance to the State Foucault was converted to become a proto-neoliberal thinker. ${ }^{16}$ Foucault himself, however, saw more continuity than discontinuity in his different research projects: 'My objective... has been to create a history of the different modes by which, in our culture, human beings are made subjects... it is not power but the subject which is the general theme of my research' (1982: 777-8).

Foucault's shepherd-God as a primary model of governing is significant for two reasons. First, this model is significant because Foucault used it as a secular model of governing that goes beyond the state and its practices of domination (which was the focus of Foucault's research throughout the 1960s and 1970s); and second, the shepherd-God served as a symbol for 'pastoral power' precisely because he (indeed, in this genealogy it is 'he' and not 'she') operates both power/domination and care, or put it differently, power-cum-care. The shepherd is the role model because he is characterized by 'devotedness' to the flock, which means that the good of the flock is his only concern; but it also means that he is watching each and every one of them all the time. In that sense the shepherd is the Balintian model of

\footnotetext{
${ }^{15}$ Mayes (2010) criticizes Foucault for providing a missing account about the figure of the 'shepherd' in both Hebraic and Christian traditions. According to Mayes, it is mainly the dimension of violence in the shepherd's role that was overlooked in Foucault's work.

${ }^{16}$ See essays in Zamora and Behrent, 2016. See also the debate of Daniel Zamora and Peter Frase in Jacobin (12.11.2014, 12.15.2014), as well as the critique of Zamora by Steinmetz-Jenkins (2015). For some interesting reflections on Foucault's approach to politics in theory and practice see the more personal book of his friend, the historian Paul Veyne (2010:111-134). Foucault mentions Veyne's work as a major influence on his later work.
} 
the 'family doctor' ${ }^{17}$ In difference from the psychoanalyst, who was trained to provide a care under the model of the maternal dyad, the GP needed to devote herself to the one (the patient) and the many (the family) at the same time:

He pays attention to them all and scans each one of them. He's got to know his flock as a whole, and in detail. Not only must he know where good pastures are, the seasons' laws and the order of things; he must also know each one's particular needs (Foucault, 1979:52). ${ }^{18}$

Thus, I would like to suggest at this point that Balint acknowledged that the medical professions are always in a danger of becoming no more than a 'pastoral technology'. Indeed, his notion of the 'apostolic function' - one that he thought of as a synonym for 'countertransference' - is precisely a demand from doctors to acknowledge their inevitable 'pastoral' tendencies over their patients. ${ }^{19}$ Moreover, one may argue that it is this pastoral role that Balint so much opposed at the beginning of his article on 'Psycho-Analysis and Medical

\footnotetext{
${ }^{17}$ For Raluca Soreanu (2018), it is perhaps not by chance that Balint was not included in Forrester's index of 'thinkers in cases', as Balint did not follow Foucault's understanding of the modern clinical sciences and their focus on 'medical examination', namely 'the written case, the case history, the "individual description", the "dossier", the "file", the procedures of writing and registration associated to the medical examination - all the documentary techniques that make each individual into a "case" and an object of a branch of knowledge' (57). However, she claims, in Balint groups, the case is spoken, and the presentation is free associative' (ibid) which makes the Balintian project to be a critique of medical power rather than an example for Foucauldian exercise of medical power. Soreanu argues that for Balint, cases should be 'spoken' precisely in order to avoid making people into 'cases' in the Foucauldian sense. I find this argument convincing to some extent, and yet problematic for several reasons. First, it attributes to Balint unjustified naivety with regard to the power-relations between doctors and patients. Balint was much more authoritarian in his practice and way of mentoring the doctors when running the first Groups in the 1950s than the way Soreanu portrayed him (see Bar-Haim, 2018). Furthermore, presenting Balint as fully committed to 'free-associations' rather than to 'the "individual description", the "dossier", the "file" ignores the fact that these meetings were documented by protocols, which are now the main archival source for any scholarship conducted on the Balint Group movement. The decision to document these meetings is a crucial element in contextualizing the Balint movement. Nor it can be easily argued for the spoken word to be considered more authentic or free than the written one, as Derrida (1976) taught us many decades ago. Finally, while I do agree that Balint was a fierce critic of power-relations in the consulting room, he - like his mentor, Ferenczi - did not have easy solutions for how to avoid them. Somehow like Forrester, Balint lived the duality of being a clear-eyed, critical observer of the psycho-medical sciences as a space of power-relations, while at the same time being a passionate advocate for developing psycho-medical methods that do not easily turn patients into merely 'cases'.
}

\footnotetext{
${ }^{18}$ More from Foucault on 'pastoral power' can be found in Foucault, 2007. The 'family doctor' is only one of several modern occupations that were shaped by pastoral power and care. For example, Hunter (1996) argued that 'the classroom is a space of ethical formation in which the students are placed under the continuous ethical supervision and problematization of a teacher who embodies both moral authority and pastoral care' (160).

${ }^{19}$ Balint suggests that in his work with GPs, he has no interest at all in what he called their 'private' transference and countertransference, only in their 'public' ones. I can see several interesting and problematic implications to such distention, but the subject deserves a much wider discussion which is beyond the scope of this article.
} 
Practice' which led him to reject the educational model in the training of GPs by psychoanalysts, as discussed above. The second model presented in 'Psycho-Analysis and Medical Practice' by the single case of Mrs. Q, - what Balint called elsewhere 'training-cumresearch' - was an attempt to problematize the 'pastoral power' in the psycho-medical professions in order to create a better epistemological framework for understanding the doctor, the patient, and the illness. This epistemological shift could occur only by thinking in cases, and moreover only by acknowledging the uniqueness of the single case study. It is the latter that requires the doctor to go beyond her theoretical knowledge to investigate the nature of the specific relationship between herself and the patient. One possible outcome of understanding this relationship, although there is no guarantee for that, is the curing of the patient. Another possible outcome is that this case study will illustrate something much wider which relates to all sorts of other cases - or what Forrester would describe as 'thinking in cases'.

However, it should also be noted that Balint never totally abandoned the medical and therapeutically framework. His interest was not purely about one's subjectivity, but also about some general knowledge that one can achieve from looking closely at a case study, partial and incomplete as this knowledge might be. ${ }^{20}$ Thus, the Balintian case study is not a form of 'self-narration', and is still vulnerable to what Matt ffytche describes in this issue as 'the illusion that there is a standpoint from which one can look at an individual subject, or an element of subjectivity, in a relatively isolated way - isolated from the broader social and historical context' (2019:??). ffytche, following Forrester, argues that the Interpretation of Dreams provides an inclusive epistemology by which, both psychical artefacts and objective facts, are useful for dissolving some artificial boundaries between one's self as pure subjectivity and one's self as the sum historical conditions for the production of one's self. Balint, however, is not interested in such dissolution of the psyche and the external world. The Balintian case study emerges precisely by the encounter of different relatively defined entities: the 'doctor', the 'patient' and the 'illness'.

\footnotetext{
${ }^{20}$ Julie Walsh suggested in this issue that 'as per the framework of John Forrester's project, the pressing methodological and epistemological challenge raised by thinking in cases concerns the possibility of moving beyond the textured singularity of the case study, to a level of reliable generality' (??). Interestingly, if one follows this definition of Forrester's project (as I do), one might locate Forrester much closer to Balint than to Freud.
} 
For Foucault, the modern welfare state was 'one of the extremely numerous reappearances of the tricky adjustment between political power wielded over legal subjects and pastoral power wielded over live individuals' (Foucault quoted in Forrester, 2017:226). Furthermore, Forrester-cum-Foucault suggested that modernity is characterized by these 'closed institutions organized on the flock principle, and moves from the monastery, via the school, the asylum, and the military barracks, to the factory and the clinic' (Forrester, 2017a: 102). No doubt that Foucault saw the modern 'psy' discourse as another major 'pastoral technology', and so did Forrester. Furthermore, the notion of 'pastoral power' helped Forrester to understand the actual role played by postwar British psychoanalysis in the building of the British welfare state and its flag project - one may say its main case-study - the National Health Service. 'When I read Winnicott's writings on medicine and case work, I cannot but link them to Michael Balint's of the same period, during which he was working with general practitioners to establish the appropriate environment and ethos of the medical system created by the National Health Service', writes Forrester(94). Winnicott and Balint, he suggested, were providers of the 'key psycho-political metaphors of British medicine and the welfare state in the period after the Second World War' (ibid). Forrester acknowledged Winnicott as such but did not have the time for presenting Balint as the other exemplar for thinking in cases of the British School of Psychoanalysis. It was this gap that this current article has aimed to fill.

\section{Acknowledgements}

I am very grateful to my colleagues, Matt ffytche, Carolyn Laubender, Alexandra Cox, Manuel Batsch, the Editors of this Special Issue, and two anonymous readers for reading earlier versions of this article, and generously suggested their useful thoughts and comments.

\section{Bibliography}

Abram, Jan (2007) The Language of Winnicott: A Dictionary of Winnicott's Use of Words. London: Karnac.

Balint, Alice, and Michael Balint (1939) 'On Transference and Counter-Transference'. International Journal of Psycho-Analysis, 20:223-230. 
Balint, Michael (1966) 'Psycho-Analysis and Medical Practice'. International Journal of Psycho-Analysis, 47:54-62

Balint, Michael (1957) The Doctor, His Patient and the Illness. Edinburgh: Churchill Livingstone, 2000.

Bar-Haim, Shaul (2014) 'Regression and the Maternal in the History of Psychoanalysis, 1900-1957'. Psychoanalysis \& History 16: 69-94.

Bar-Haim, Shaul (2017) 'The Child's Position: The Concept of Childhood in Interwar Psychoanalysis', in Fragile Subjects: Child Figures in Western Modernity, ed.by Jutta Ahlbeck et al. NY: Routledge.

Bar-Haim, Shaul (2018)'"The Drug Doctor": Michael Balint and the Revival of General Practice in Postwar Britain'. History Workshop Journal 86:114-32.).

Behrent, Michael C (2016) 'Liberalism without Humanism: Michel Foucault and the Free Market Creed, 1976-1979'. In Zamora, Daniel and. Behrent (eds.) Foucault and neoliberalism. Cambridge: Polity Press.

Borgos, Anna (2019) 'Alice Bálint and Her Diaries: ‘... This little fixation seems to remain ...'. Psychoanalysis and History 21: 23-52

Burchell et al. (1991) The Foucault effect: studies in governmentality: with two lectures by and an interview with Michel Foucault. London: Harvester Wheatsheaf.

Davidson, Arnold I. (2011) 'In praise of counter-conduct'. History of the Human Sciences 24 (4): $25-41$.

Derrida, Jacques (1976) Of grammatology. Baltimore: Johns Hopkins University Press.

Erős, Ferenc (2012) 'Some Social and Political Issues Related to Ferenczi and the Hungarian School'. In Ferenczi and His World: Rekindling the Spirit of the Budapest School, ed. by Judit Szekacs-Weisz and Tom Keve. London: Karnac. 
Ffytche, Matt (2019). 'Throwing the case open: the impossible subject of Luisa Passerini's Autobiography of a Generation'. History of the Human Sciences.

Forrester, John (2017a) Thinking in Cases. Cambridge: Polity Press.

Forrester, John (2017b) 'Foucault, Power-Knowledge and the Individual'. Psychoanalysis and History 19:215-232.

Foucault, Michel (1979) 'Politics and Reason'. In: Foucault Michel, Kritzman Lawrenece (eds) Politics, Philosophy, Culture : Interviews and Other Writings, 1977-1984. Hoboken: Routledge, 2013.

Foucault, Michel (2007) Security, Territory, Population: Lectures at the Collège de France, 1977-1978. New York \& Basingstoke: Palgrave Macmillan.

Foucault, Michel (1982)'The Subject and Power'. Critical Inquiry 8 (4):777-795.

Frase, Peter (2014) 'Beyond the Welfare State'. Jacobin 12.11.2014:

https://www.jacobinmag.com/2014/12/beyond-the-welfare-state/

Freud, Sigmund (1905 [1901]) 'Fragment of an Analysis of a Case Previous of Hysteria' (1905 [1901]). The Standard Edition of the Complete Psychological Works of Sigmund Freud, Volume VII (1901-1905): A Case of Hysteria, Three Essays on Sexuality and Other Works. London: Hogarth Press.

Golder, Ben (2007) 'Foucault and the Genealogy of Pastoral Power'. Radical Philosophy Review 10(2): 157-176.

Hayward, Rhodri (2014) The transformation of the psyche in British primary care, 18701970. London: Bloomsbury. 
Hunter, Ian (1996) 'Assembling the school'. In Andrew Barry, Thomas Osborne, Nikolas Rose (eds.) Foucault and Political Reason: Liberalism, Neo-Liberalism And The Rationalities Of Government. London: UCL Press.

Kohon, Gregorio (ed.) (1985) The British School of Psychoanalysis: The Independent Tradition. London: Free Association, 1985.

Kuhn, Thomas S. (1996 [1962]) The structure of scientific revolutions. Chicago: University of Chicago Press.

Laplanche, Jean and J. B. Pontalis (1988) The Language of Psycho-analysis. London: Karnac and the Institute of Psycho-Analysis.

Leshem, Dotan (2015) 'Embedding Agamben's Critique of Foucault: The Theological and Pastoral Origins of Governmentality'. Theory, Culture \& Society 32 (3):93 - 113.

Little, M.I. (1985) Winnicott working in areas where Psychotic Anxieties predominate: A personal record. Free Associations 1(3):9-42.

Mayes, Christopher (2010) 'The Violence of Care: An Analysis of Foucault's Pastor'. Journal of Cultural and Religious Theory 11(1):111 - 126.

Osborne, Thomas (1993) 'Mobilizing Psychoanalysis: Michael Balint and the General Practitioners'. Social Studies of Science 23:175-200.

Rudnytsky, Peter L., Antal Bokay, and Patrizia Giampieri-Deutsch (eds.)(1996), Ferenczi's Turn in Psychoanalysis. New York: New York University Press.

Sklar, Jonathan (2017) Balint matters: psychosomatics and the art of assessment. London: Karnac.

Shapira, Michal (2017) "Interpersonal rivalries, gender and the intellectual and scientific making of psychoanalysis in 1940s Britain.” History of Psychology 20:172-194. 
Shapira, Michal (2013) The war inside: psychoanalysis, total war, and the making of the democratic self in postwar Britain. New York: Cambridge University Press.

King, Pearl and Riccardo Steiner (1991) The Freud-Klein controversies, 1941-45. Hove: Brunner-Routledge.

Steinmetz-Jenkins, Daniel, and Alexander Arnold (2015) 'Searching for Foucault in an Age of Inequality' Los Angeles Review of Books 18 March 2015:

https://www.lareviewofbooks.org/article/searching-foucault-age-inequality/

Swerdloff, Bluma (2002) 'An Interview with Michael Balint. The American Journal of Psychoanalysis, 62(4):383-413.

Winnicott, D. W. (1965) 'A Child Psychiatry Case Illustrating Delayed Reaction to Loss'. In: Psycho-Analytic Explorations. London: Karnac Books, 1989.

Tauber, Alfred I. (2009) 'Freud's philosophical path'. The Scandinavian Psychoanalytic Review 32 (1):32-43.

Veyne, Paul (2010) Foucault: his thought, his character. Cambridge : Polity

Young-Bruehl, Elisabeth (2002) 'A visit to the Budapest School'. Psychoanalytic Study of the Child 57:411-32

Zamora, Daniel (2014) 'Foucault's Responsibility'. Jacobin 12.15.2014:

https://www.jacobinmag.com/2014/12/michel-foucault-responsibility-socialist

Zamora, Daniel and Michael C. Behrent (eds.) (2016) Foucault and neoliberalism. Cambridge: Polity Press. 